\title{
EXPLORING STUDENTS' AFFECTIVE ON USING ASYNCHRONOUS LEARNING DURING THE PANDEMIC PERIOD
}

\author{
Yudha Andana Prawira \\ Badan Litbang dan Diklat Kementerian Agama \\ Jl. M.H. Thamrin Jakarta, Indonesia, 10340 \\ Email:yudhaandanaprawira@kemenag.go.id.
}

\section{Vidia Lantari Ayundhari}

Balai Diklat Keagamaan Bandung

Jl. Soekarno-Hatta, Bandung, Indonesia, 40295

Email:vidialantariayundari@kemenag.go.id.

\section{Titim Kurnia}

Dinas Pendidikan Kota Bandung

Jl. Ahmad Yani, Bandung, Indonesia, 40171

Email75titimkurnia@gmail.com

Received: 09, 2020. Accepted: 06, 2021. Published: 06, 2021

\begin{abstract}
The distance learning can greatly improve student's cognitive development, but its success in increasing students' affective competence have not been conclusively reported. This study aims to investigate students' affective aspects, parents, and teacher perspective on Islamic religious education using asynchronous learning. Data were collected using questionnaires, interview, and observation. The data were analysed using descriptive analysis. The results show that there was a change on students' competence in terms of affective religious aspects. Initially $60 \%$ students have negative attitudes and decreased to $30 \%$ after they had experienced asynchronous distance learning with commitment of learning establishment. The parents in their interview expressed that they were greatly assisted by the commitment of learning their children formed. The asynchronous learning with learning commitment can be considered successful to help students improve their attitudes. This study shows that e-learning accompanied by a learning commitment between student and teachers turns out to be able to give positive results on the part of students' affective on Islamic religious education.
\end{abstract}

Keywords: Asynchronous Learning, Islamic Religious Education, Learning Commitment, Students' Affective

\begin{abstract}
ABSTRAK
Pembelajaran jarak jauh dapat meningkatkan perkembangan kognitif peserta didik, tetapi keberhasilannya dalam meningkatkan kompetensi afektif peserta didik belum dilaporkan secara meyakinkan. Penelitian ini bertujuan menginvestigasi aspek afektif peserta didik, pandangan orang tua, dan pendidik terbadap pendidikan agama Islam dengan pembelajaran asynchronous. Pengumpulan data dilakukan dengan menggunakan kuesioner, wawancara, dan observasi. Analisis data menggunakan analisis deskriptif. Hasil penelitian menunjukean babwa terdapat perubahan kompetensi peserta didik ditinjau dari aspek afektif keagamaan. Peserta didik awalnya memiliki sikap negatif 60\% kemudian menurun menjadi 30\% setelah mereka mengalami pembelajaran jarak jauh asinkron dengan komitmen kemapanan pembelajaran. Orang tua dalam wawancaranya mengungkapkan babwa mereka sangat terbantu dengan komitmen belajar yang dibentuk anaknya. Pembelajaran asinkron dengan komitmen belajar dapat dianggap berhasil membantu peserta didik meningkatkan sikapnya. Penelitian ini menunjukkan babwa e-learning yang disertai dengan komitmen pembelajaran antara peserta didik. dan pendidik mampu memberikan hasil yang positif bagi afektif peserta didik terhadap pendidikan agama Islam.
\end{abstract}

Keywords: Afektif Peserta Didik, Komitmen Belajar, Pembelajaran Asynchronous, Pendidikan Agama Islam 


\section{INTRODUCTION}

Covid-19 has a huge impact on human life today, including in the educational environment. During the Covid-19 pandemic, face-to-face learning is strictly avoided to prevent the spread of the virus. Thus, distance learning, which was previously unpopular and tended to be avoided, is now a necessity. Several studies on distance learning before the pandemic have been suggested, among others Moore, Dickson-deane, \& Galyen (2011), Dickey \& Dickey (2003), and Mignon \& Umr (2012). They generally still consider the pros and cons of distance learning.

Research focuses on the acquisition of skills through distance learning. The areas or aspects of student competence that need to be mastered are three areas (Bloom et al., 1956). The three skill areas attained by students, appear difficult to attain by distance learning systems. Distance learning is due to the limited interaction between teachers and students (Rahmawati, 2009). However, with the Covid-19 pandemic, distance learning has become necessity. It required effort to overcome the limitations of distance learning. This study highlighted some of the weaknesses of distance learning in the cognitive and affective domains (Gazali, 2018).

The main difficulty of distance learning education is the acquisition of emotional skills. This is because students' emotional aspect is fundamental for their development. The foundation of the pupil's emotional will be the development of the pupil's character. In Indonesia, character education has been promulgated by Presidential Decree No. 87 of 2017, which emphasizes student character formation and technological developments and the era of globalization. The limitation of communication between teachers and students might contribute to the difficulty to reach the affective domain (Holotescu, Grosseck, \& Danciu, 2014). This incident occurs mainly in developing countries, such as Indonesia, which geographically has a high level of difficulty in the availability of distance learning facilities. Adaptation is needed to move from face-to-face learning to distance learning ( $\mathrm{Vu}$, Hoang, \& Than, 2020).

Several other studies discussing the effectiveness and constraints faced by distance learning. Chertoff reported that the hardware is the main problem for distance learning to smoothly run (Chertoff et al., 2020). In addition to hardware issues, distance learning has another issue dealing with the network. Internet network has a difficulty to reach an interior areas or remote areas to cover. These problems not only happen at the high school level, even at the college level, students face the same problems when participating in distance learning (Hasanah et al., 2020).

Other issues regarding distance learning have been published by scholars. A research reported distance learning from the point of view of students' parent (Abuhammad, 2020b) other researcher investigated also the issue of using social media as a learning medium to facilitate distance learning (Tayo et al., 2020). Other researchers examined the adaptation of remote learning if it last longer (Qazi et al., 2021) and how to assess the distance learning (Saidi et al., 2021). Other researchers investigated the effectiveness of distance learning (Adams \& Cross, 2000; Iswandi, 1999; Davis et al., 2021; Fagel, 2020).

In general, distance learning can be categorized into two parts, namely synchronous and asynchronous. This is to say that both synchronous and asynchronous enable distance learning to be implemented (Ningsih, 2020). Several synchronous research reports have been put forward. The issues include: distance learning designs are synchronous (Bower et al., 2015); the influence of synchronous and asynchronous learning styles on learning outcomes (Mehri \& Uplane, 2015) the development of distance learning (Groumpos, 2018; Chen et al., 2021).

Research on distance learning using both synchronous and asynchronous has reported its advantages and disadvantages. The magnitude of the advantages and disadvantages of 
distance learning influenced by various factors, such as teachers, facilities, and students. Synchronous distance learning has several advantages such as supporting the development of an adequate earning environment (Dickey \& Dickey, 2003). Distant learning can also help students' learning mental resilience (Davis et al., 2021). In addition, there are also research results that reveal asynchronous distant learning can also make a positive contribution to learning (Christopher et al., 2020; Allen, 2017). Chen et al. (2021) stated that distance learning really helps the learning process because students have learning time that is adjusted to their schedule. This is different from synchronous distance learning which requires students to manage their time in learning as regular face-to-face learning.

There are also researchers who combine the distance learning process between synchronous and asynchronous patterns, which is known as blended distance learning. This topic has been studied by Bower et al. (2015) and Szeto (2014). They reported that blended distance learning provides sufficient space for teachers and students to explore themselves. This is mainly to overcome the saturation of synchronous learning. In fact, both students, teachers, and parents of students feel unhappy during distance learning synchronously because they feel they are in prison. It is difficult for both the teacher and students to create and innovate in teaching and learning (Fagel, 2020)

Students' competence for affective domain can still be acquired in distance learning. Several studies reveal that students' emotional competence can be acquired through distance learning (Jena, 2020). In several sociological aspects, Indonesia and India have several similarities. Another study reporting the results of distance learning research by taking the middle way, namely blended learning between synchronous and asynchronous (Lapitan et al., 2021; Bower et al., 2015). The model of learning should be changed to increase the effectiveness and success of distance learning. If distance learning encounters problems in aspects of internet facilities and networks, it can be overcome by applying asynchronous distance learning models.

One of the affective aspects that can be studied is the affective aspect of religiosity. When it comes to learning, students' religiosity is the foundation of their character development. Keow et al. (2015) said, there is a need to instil an attitude of religiosity in students as part of their soft skills. In Indonesia, the curriculum for primary and secondary schools designs religious affective competence to achieve. Students should demonstrate their obedience to the rules of their religion and their acceptance on individual diversity as the gift from God. They should exhibit behaviours like: polite, harmonious, independent, confident, and cooperative attitudes.

The affective aspect should be featured in all subjects taught in the school. One of the subjects is Islamic religious education for elementary schools. One of the functions of Islamic religious education is to form a religious character in accordance with the values of national education (Ayuhana, 2015). Student character can be formed on of through Islamic religious education has also been expressed by Nasih et al. (2020) which states that Islamic religious education can shape the character of students. Asfiati (2017) said, the need for an analysis of basic competencies in Islamic religious education. Amilda \& Wati (2016) states that to realize character through Islamic religious education, proper management is needed. It is expected that by conducting Islamic religious education, the schools can contribute to their students' character development in an integrative manner (Hidayat et al., 2020).

The government has regulated Islamic religious education curriculum for elementary schools. In accordance with the Regulation of the Minister of Education and Culture Number 37 of 2018, the basic competencies of Islamic religious education include accepting and carrying out the teachings of their religion, getting used to praying before and after learning, 
and believing that respectful and obedient behaviour to parents and teachers is a reflection of faith.

The competence of students in this aspect of religious attitudes is at the centre of the research. These attitudes serve as the basis for the instrument to reach the affective aspect of religion. Regarding this aspect of religious attitudes, the United States and Europe are also developing education based on religion. In the culture of learning based on Islam, it has four pillars, namely that learning is indicated by changes in behaviour resulting from experience, learning means observe, read, imitate, try, listen, learning is marked by changes in performance and this learning is a process or a procedure (Baroroh, 2004). The limitation of religious affective competence that will be examined in the research also refers to Baroroh's opinion. In addition, it is necessary to increase this affective aspect is to build better student character (Baharun \& Maryam, 2019; Nasih et al., 2020)

Commitment to learn is one of the important aspects of successful teaching, as stated by Porter as the need for clarity of purpose and commitment to solidarity to achieve learning goals (Porter \& Latham, 2013). The need for an attitude of commitment to achieve learning objectives (Mercurio, 2015). Learning commitment need to be establishing in carrying out this distance learning. Several studies on the importance of engagement in learning have also been proposed by Hakim (2016) and Rosdiana (2013). They said the existence of a commitment to learning between students and teachers had a positive effect on student achievement. Commitment formation need before learning make emotional commitment, normative commitment, and sustainable commitment (Atak \& Erturgut, 2010). The forms of building learning commitment that can be built between teachers, students, and parents of students (Khunsoonthornkit \& Panjakajornsak, 2018; Zainuddin \& Kamaluddin, 2012). This commitment includes time commitment, commitment to material boundaries and learning objectives, commitment in implementing communication, and commitment to maintaining comfort during the implementation of distance learning (Hanaysha, 2016). This is included in the affective aspect of the religious. The commitment to learning exists between teacher and students and it is hoped that all obstacles of distance learning can be overcome. Strengthening the internet network is needed to develop asynchronous distance learning (Shahabadi \& Uplane, 2015; Chen et al., 2021). The results of asynchronous learning can also provide significant benefits as stated Shahabadi \& Uplane (2015) that in order to optimize synchronous learning, assimilation and divergence carried out by teachers is needed according to the character of the students. Meanwhile, for asynchronous learning, assimilation and convergence patterns are needed.

Based on literature review and surveys in several schools, there is a gap between the needs for achievement of student competencies affective among cognitive and psychomotor competencies, particularly during the Covid-19 pandemic. The distance learning pattern is needed to achieve student competence, particularly asynchronous distance learning through commitment to learning.

There is a lot of research on asynchronous distance learning in higher education. However, little information about asynchronous learning is accompanied by a commitment to learning to improve the religious affective aspects of students in elementary schools. This study aims to investigate the implementation of distance learning involve students' progress in the affective aspects, parents' responses, and teachers' perception on the success of asynchronous distance learning with learning commitment during the Covid-19 pandemics.

\section{METHOD}

This study uses a qualitative approach with descriptive analysis techniques (Cai \& Mehari, 2015; Sugiyono, 2014) and purposive sampling approach (Creswell, 2014). Participants 
in this study were teachers, students and parents of grade VI students at one of the state elementary schools in Cluster 1 of the Subdistrict Education Office in Bandung City. Respondents consisted of three groups, namely teachers, students, and parents of students. The data collection for students uses a questionnaire, while for teachers and parents using interview guidelines. The data collected were in the form of questionnaires, interviews, and observations, then analysed. The instrument for students in the form of a questionnaire about the competence of the affective aspects of the researcher adopted and modified the instrument developed (Fadillah, 2017). The questionnaire used was validated by evaluation experts, material expert lecturers, and elementary school class teachers who had more experience. Instruments for students relate to comfort during the implementation of elearning, their attitudes and expectations during e-learning, and measuring indications of changes in their religious attitudes. Instruments for teachers relate to teaching methods and approaches. While the instrument for parents of students is used for triangulation. Researchers adopted interview guides from experts (Soegijapranata, 2016).

\section{RESULTS AND DISCUSSION}

The researcher needs to reiterate that the purpose of this study is to find out changes in students' attitudes during distance learning and how the role of parents in helping distance learning. Based on a survey of students and interviews with parents, we can explain during asynchronous distance learning with learning commitments that $75 \%$ of students experienced a more positive attitude change. However, this study still has weaknesses because there are still $4 \%$ of students who do not change their attitude. After being traced through triangulation, the cause was due to psychological factors at home, so that learning commitments could not be fully implemented. Likewise, from the results of interviews with parents, they responded that distance learning accompanied by commitment had a positive impact on changes in students' attitudes while studying at home. Parents feel a lot of improvement in attitude after being given action in the form of learning commitment, even without directly meeting the teacher. Thus, the purpose of this study is to set an example for other schools.

\section{Students' Change in Attitudes}

Using the questionnaire for collecting the data, the researcher can present some of the findings from the results of the student questionnaire tracing. The data collected from the questionnaire is a student self-evaluation regarding changes in student attitudes during asynchronous distance learning. There are aspects of attitude that are asked of students, among others, regarding the behavior of students during their daily learning at home, especially those with regard to worship, student behavior towards assignments from their class teachers, and student behavior towards their parents.

Table 1. illustrates students' behavior from the their daily basis and their religious behaviour while studying at home. 
Table 1. Changes in Student Behavior in Affective Aspects at Home and Worship

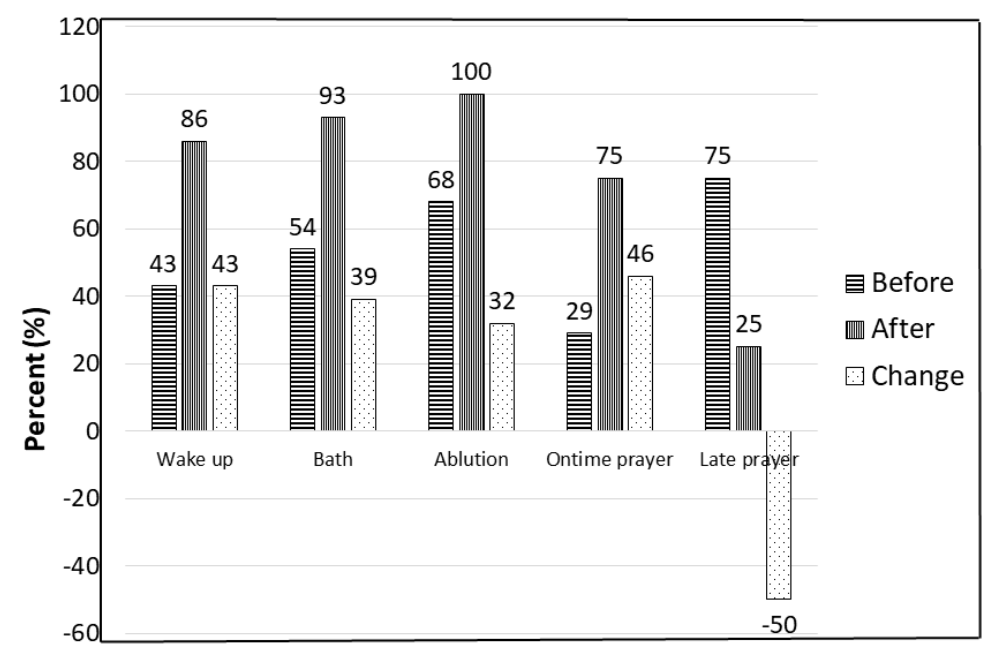

Based on Table 1, it can be explained that the behavior of the students according to the presented questionnaire can be compared to a positive attitude change. For example, $43 \%$ of waking behaviors before building learning commitment (BLC) never wake up late, during distance learning after BLC wakes up on time at $86 \%$. For there to be a positive change in the percentage. Only 14\% are still late. Likewise with the eagerness to bathe in the morning. Previously, only $53 \%$ of students took a quick shower, compared to $93 \%$ of students who took a quick shower, and only $7 \%$ of students were still lazy to shower.

Covid-19 has A tremendous impact on education sector in many countries. Responding to this pandemic, all education institutions have tried to implement distance learning. Several studies on distance learning before the pandemic have been reported in several reputable journals. Among others Moore et al. (2011), Dickey \& Dickey (2003), and Mignon \& Umr (2012). Those researchers have reported the pros and cons when it comes to the implementation of distance learning.

Research focuses on the acquisition of skills through distance learning have been reported. The research reported the areas or aspects of student competence that need to be mastered are three areas (Bloom et al., 1956). The three skill areas attained by students, appear difficult to attain by distance learning systems. Those skills might be difficult to attain by teachers during distance learning because of limited interaction between teachers and students (Rahmawati, 2009). However, with the Covid-19 pandemic, distance learning has been considered as viable and possible approach to facilitate education.

Students' attitude and their behaviors should be taken into consideration by the teachers during pandemic and distance learning. It required effort to overcome the limitations of distance learning. The students' behaviours should be monitored when it comes to their learning activities. There are weaknesses of distance learning in the cognitive and affective domains (Gazali, 2018).

In accordance with the purpose of this study to examine changes in certain aspects of religious attitudes, there are two aspects of the requested instrument, namely with regard to wudu and the timeliness of prayers. Before distance learning with BLC, $68 \%$ of students were diligent in ablutions, after distance learning and BLC were $100 \%$ diligent in ablutions. Also, regarding the on time of prayer, originally only $29 \%$ of students prayed on time, after distance learning with BLC became $75 \%$ praying on time. This means that only up to $25 \%$ are often late for prayers. If we observe in the photo at the end or on the far right the delay of the students, there is a significant increase, for example distance learning before BLC is still $75 \%$ late in prayer. After distance learning with BLC, only $25 \%$ of students are still late in prayer, 
this shows that $75 \%$ are already on time to pray. The results of this data, of course, are only from the perspective of the student, so it remains to be verified by triangulation of the parents of the students.

Table 2. Recognition of Students in doing Assignments from the Teacher

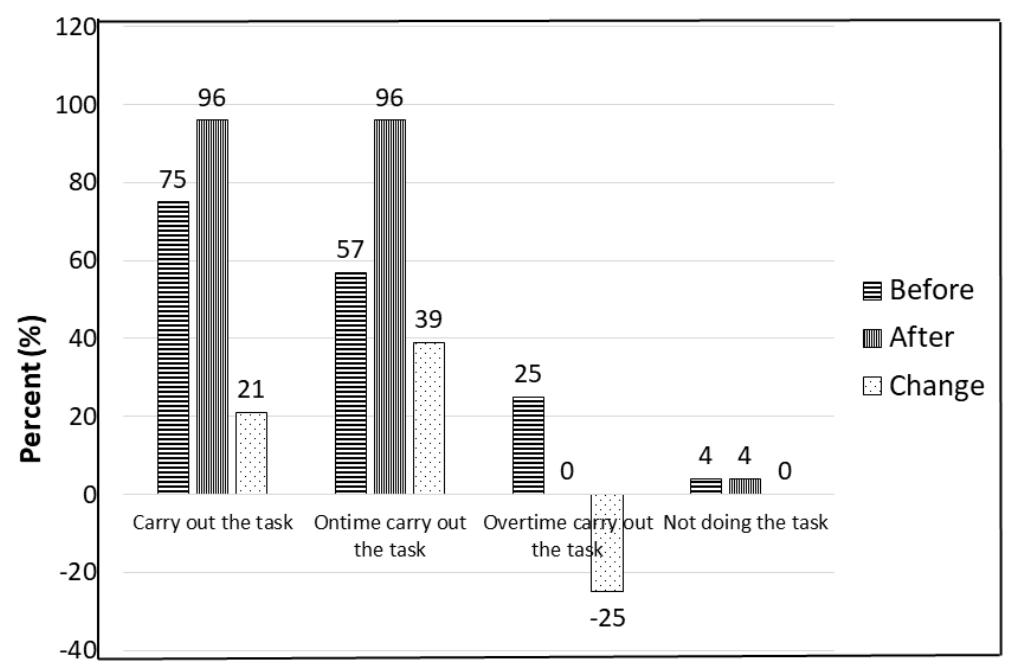

Based on Table 2, the next data the researcher was able to reveal was that there were also positive changes in students' attitudes to doing teacher homework. In this case, what is said is only the attitude to continue with the task, but not up to the results of the task. Because the quality of the work given by the students is included in the cognitive and psychomotor aspects. For the data below to show only the percentage of students who complete homework correctly, the percentage who delay in completing their homework, and the percentage of students who do not complete homework. From the table above, it can be described that prior to distance learning with BLC, only $75 \%$ of students were doing their homework (either on time or late), which means that $25 \%$ of students were not doing their homework. However, after distance learning with BLC, $96 \%$ of students did their homework, meaning that there was still $4 \%$ of students who did not do their homework.

From the point of view of accuracy in delivering homework to teachers, before distance learning with BLC was only $57 \%$ on time to do teacher homework, after distance learning with BLC became $96 \%$ of the students on time. However, there is still $4 \%$ of students who are late/not doing their homework. However, which is unfortunate in the findings of the researchers, there are still $4 \%$ of students who until the end of the study still did not do their teachers' homework. These are the duties that the primary teacher must fulfill. However, it is regrettable, there are still $4 \%$ of students who do not do assignments at all. To follow up, the teacher contacted the parents of students. The search results show that the student has family problems with his parents. In this case, the teacher has limitations to solve it.

The main difficulty of distance learning education is the acquisition of emotional skills. This is because students' emotional aspect is fundamental for their development. The foundation of the pupil's emotional will be the development of the pupil's character. Their character influences their decision to work on their assignment during distance learning. It is not easy for the teachers to encourage students to work on their assignment. The limitation of communication between teachers and students might contribute to the difficulty to reach the affective domain (Holotescu et al., 2014). This is very common and it may happen in developing countries, such as Indonesia. Indonesia which geographically has a high level of difficulty in the availability of distance learning facilities. It requires special treatment and 
effort from the government to deal with the changing approach for educational purposes. Adaptation is needed to move from face-to-face learning to distance learning (Vu et al., 2020).

Several other studies discussing the effectiveness and constraints faced by distance learning. Chertoff reported that the hardware is the main problem for distance learning to smoothly run (Chertoff et al., 2020). In addition to hardware issues, distance learning has another issue dealing with the network. Internet network has a difficulty to reach an interior areas or remote areas to cover. These problems not only happen at the high school level, even at the college level, students face the same problems when participating in distance learning (Hasanah et al., 2020).

\section{Student responses toward the implementation of distance learning using BLC}

Another findings during the distance learning were came from students. The survey's results were to dig into student's reflections and described in the Table 3.

Table 3. Students' Attitudes towards Distance Learning

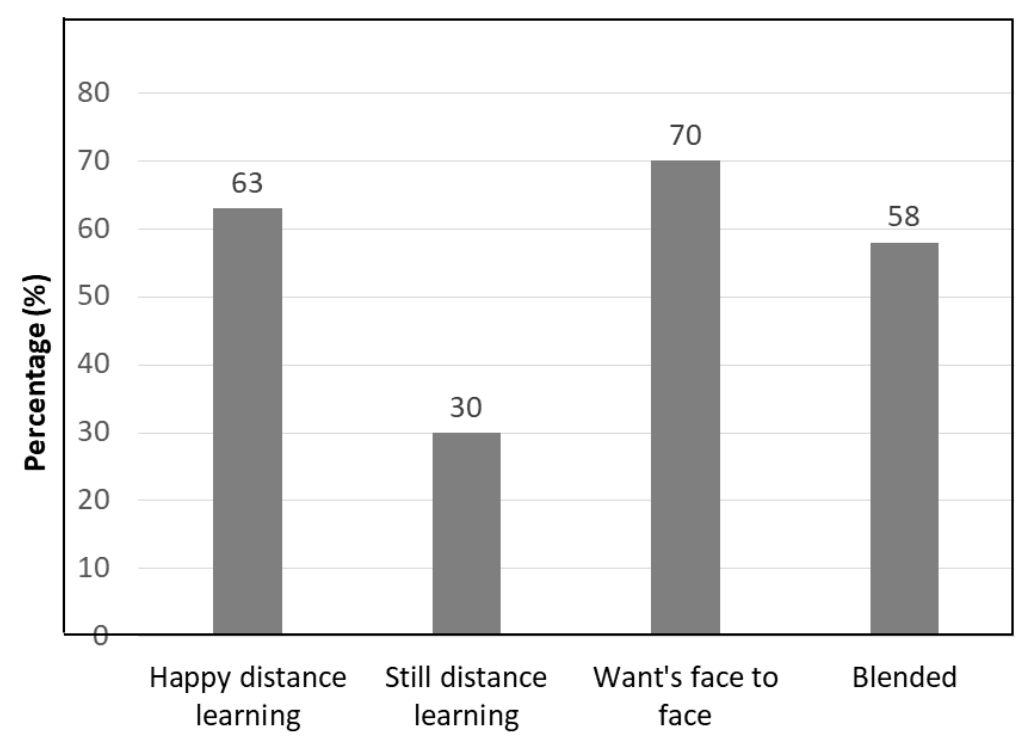

Based on Table 3, it can be observed that as many as $63 \%$ of students feel happy with distance learning by e-learning. However, when students were asked about this e-learning that needed to be continued or stopped, it turned out that only $30 \%$ still wanted to implement elarning, while $70 \%$ of students wanted face-to-face learning. This shows that although elearning is quite enjoyable for students, the majority do not want to continue to implement elearning. This is an anomaly that needs to be examined in more depth.

Based on the researcher's in-depth study of students' parents and virtual interviews with students, even though students like e-learning, they still want face-to-face learning. However, this study found that there was also a kind of anomaly or anomalies between the needs and desires of distance learning from a student's point of view. This anomaly can occur as suggested (Schaible et., 2020). The findings it has been found that students are happy with distance learning. Students' enjoyment of asynchronous distance learning certainly has different reasons. Most of the students were happy. In the view of researchers, logically, people who feel happy about something, of course, want to continue their pleasure. However, from the data found, students who felt happy with distance learning did not want to continue this distance learning. Students want face-to-face learning

\section{Parents' Perception on Students' Progress}

The next data that researchers can reveal is the result of data collection through interviews with students' parents. This interview data the researcher used as a triangulation of 
the student questionnaire data. Is the recognition of students in filling out this questionnaire in line with recognition from their parents or vice versa. If it is aligned, it means that distance learning with BLC will really have benefits in improving the affective aspects of students, especially in affective religious. Conversely, if it is not in line with the statements of parents and the recognition of students, it means that there are still obstacles in the implementation of distance learning with this BLC.

As an illustration of the interview guide for the parents of this student regarding the response of parents to changes in their children's behavior, the response of parents to their teachers; as well as parents' expectations for the continuation of distance learning with this BLC.

The following is an example of a statement by a student's parent.

Student parrent's 1: $\quad$ My son wil bee pray

Thank you, Mrs, for your attention for my son

Please distance learning back to face to face

Student parrent's 2: $\quad$ I hope Asep (my son) will be better

Thank you Mrs, for your motivation

We want be back learning face to face

Student parrent's 3: $\quad$ My daughter has become more diligent in worshiping

Thank you Mrs

Student parrent's 4: My son has been educating and giving knowledge to Zulfikar so far, hopefully the knowledge that you have given is useful for Zulfikar, on behalf of Zulfikar's parents, I am very grateful

Student parrent's 5: All must feel the same ma'am. But what can I do? The health and safety of all of us is also very important.

Thank you for the efforts of the mother who always monitors my child's learning NN (coincidentally this student has special needs \#notes from the homeroom teacher). Very useful for all of us.

Student parrent's 6: Thank you ma'am, always remind Fahri and give encouragement

Student parrent's 7: Thank you your attention, we hope learning face to face again

Student parrent's 8: Thank God, my child is playing the game a bit less

Based on some examples of Student's statements, it can be described that all of the parents' statements are statements that are positive in tone. Student's statement's of course is in line with the admissions of students who stated that some attitudes and behaviors also experience changes in daily behavior at home. This shows that, the implementation of distance learning with BLC which is implemented has a positive impact on changes and developments in the attitude/affective aspects of students.

Although all of student's opinions are positive about the distance learning process that has been carried out so far, it seems that all students want to go to classical or face-to-face learning patterns in class. Some students mentioned the reason for wanting to return to faceto-face learning, because they felt that although affective attitudes, especially religious, experienced a positive change, in terms of knowledge and skills competencies, some people felt unable to guide their children.

A research reported distance learning from the point of view of students' parent (Abuhammad, 2020b). Using social media as a learning medium to facilitate distance learning has been reported by the researcher (Tayo et al., 2020). The issue on the adaptation of remote learning if it last longer has been studied by researcher. This may be the big problem for the parents because they have to deal with their children learning (Qazi et al., 2021). Parents may also spend their attention to their children when they took their assessment (Saidi et al., 2021). 
Parent have also contributed to the successful implementation of distance learning (Adams \& Cross, 2000; Iswandi, 1999; Davis et al., 2021; Fagel, 2020).

Research on distance learning using both synchronous and asynchronous has reported its advantages and disadvantages. This information can be valuable for the parents when it comes to distance learning implementation for their children. Parent in this pandemic situation also consider that distance learning can be a way to solve inadequate learning environment (Dickey \& Dickey, 2003). Distant learning can also help students' learning mental resilience (Davis et al, 2021). Parents may also take into consideration research results that reveal asynchronous distant learning can also make a positive contribution to their children distance learning (Christopher et al., 2020; Allen, 2017). In the same vein, Chen et al. (2021) reported that distance learning really helps the learning process because students have learning time that is adjusted to their schedule. Parents observe this situation when their children participate in distance learning. This is different from synchronous distance learning which requires students to manage their time in learning as regular face-to-face learning.

\section{Teacher's Opinion on Students' Performance}

\section{Students' Change in attitude from Teacher's Point of View}

The change in student attitudes according to the teachers during distance learning is somewhat different. It is because teachers cannot see directly the change experienced by students. Teachers can only interpret from the image captions obtained through their learning process while doing works. Although it does not observe directly, it observes through the work conveyed. It is conducted through student photos submission when working on the assignment. Thus, although the teacher does not observe directly, the photos sent by parents were observable still. Here's a percentage of change in students' attitudes when studying, doing, or submitting assignments.

Table 4 Teacher's Views

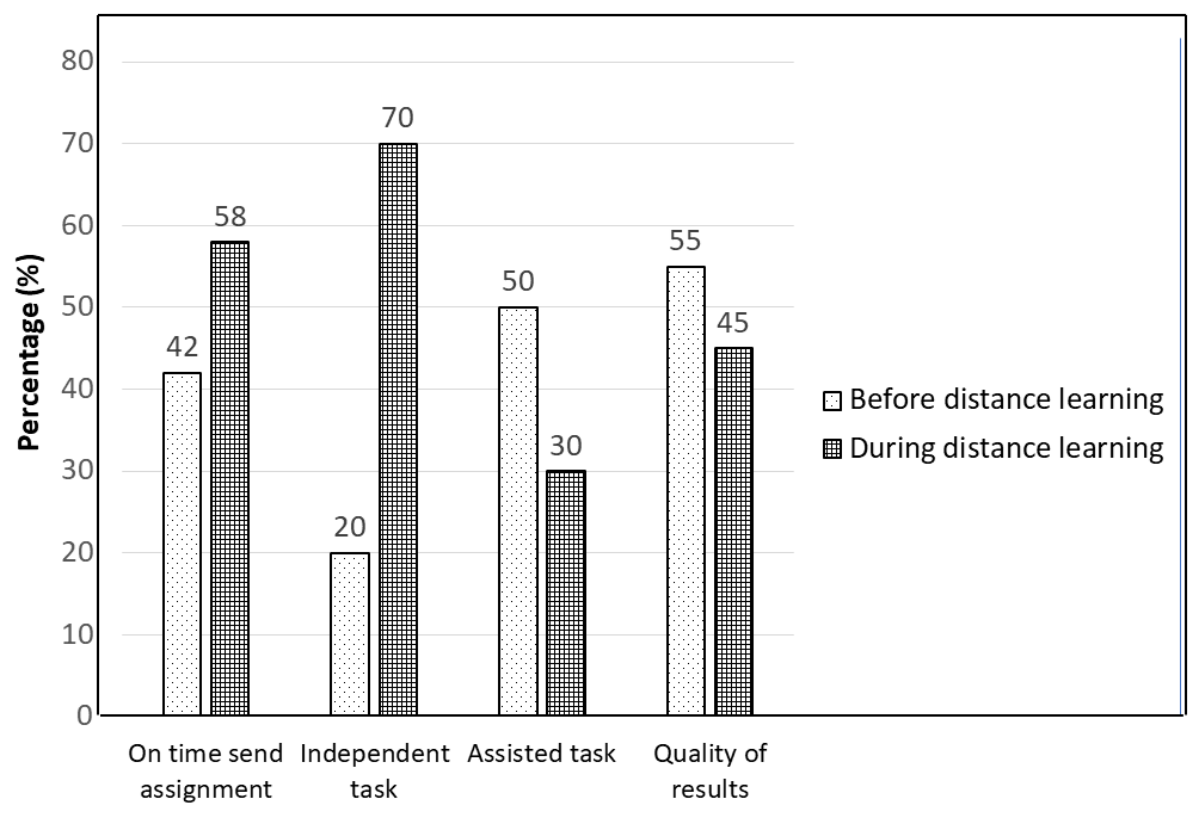

Based on the Table 4, the four aspects of teacher's assessment are becoming focuses to students. Seriousness, accuracy and speed, has high percentage with good criteria. Researchers conduct cross-checks and observe photos while doing chores. The observation results show body attitude. Students doing tasks with various poses. Some sitting upright at the table, relaxing, or even facing down. In the accuracy of sending assignments by e-learning the 
students experienced a slight increase, from the original $42 \%$ to $58 \%$. Although the increase is slight, it is sufficient to make a positive contribution to changes in affective competence. A striking change occurs when doing independent assignments, which when they have not carried out a learning commitment, $70 \%$ of students are still always assisted by others. However, after carrying out the learning commitment, it increased to only $30 \%$ who were still assisted when doing their assignments. Meanwhile, from the aspect of the quality of the assignment results, during the implementation of e-learning, there was a decline, which was originally $55 \%$ in the good category, while only $45 \%$ were in the good category during elearning.

\section{Student Questionnaire Findings}

Based on the research findings as described in the previous section, also referring to the problem question, the analysis of these findings can be explained as follows. First, regarding the affective aspects of religious students who experience positive changes. The religious aspect for elementary school level students is of course different from the higher level. What is meant by the aspect of a religious attitude is simply an increase in the willingness to carry out routine worship according to one's religion. For example, as shown in the findings section of the study, students who were initially reluctant to carry out worship turned out to be willing to carry out routine worship (Table 1). Students who at first were often late in carrying out routine worship, changed to worship according to the set time. As well as students who were previously good at carrying out routine worship increased with other circumcision worship. To triangulate research on student subjects, researchers interviewed Student's participants. Interviews with Student's students as an effort to triangulate and collect research data, this is in accordance with what was stated (O'Leary, 2019) and (Arulogun et al., 2020) that in order to broaden the researcher's ideas and insights, triangulation data is needed.

In this study, one of the triangulation data sources was parents participants. Most parents feel happy because their children have an increase in carrying out routine worship. Some parents also feel happy because their children experience changes when they help their parents. When Student's students were asked why there could be changes in the attitudes of their children, even though students did not meet the teacher directly. Student's answer is that if the child has difficulty carrying out routine worship or is lazy to help parents with homework, the student's parents will ask the teacher for help to contact their child directly either by telephone or by video connection. The results of this study are in line with his opinion (Saidi., 2021) that students can adapt to the distance learning process due to teacher guidance. Similarly, opinions (Qazi et al., 2021) dan (Abuhammad, 2020a).

Based on these findings, the implementation of distance learning with BLC can be considered to have contributed to improving the affective aspects of the religious students. This building learning commitment is beneficial as are the results of the research presented who stated that the building learning commitment has several advantages, including motivating and facilitating parents and students. In addition, that the research results are also in line with the theory put forward (Costa et al., 2020) in their research which states that "Distance Education (DE) associated with the use of Virtual Learning Environments (VLE) as interaction tools between the student and the educator has become a large research niche spread around the world".

Commitment to learn is one of the important aspects for the teachers to achieve their successful teaching, as stated by Porter as the need for clarity of purpose and commitment to solidarity to achieve learning goals (Porter \& Latham, 2013). Students should demonstrate their need for an attitude of commitment to achieve their learning objectives (Mercurio, 2015). When it comes to education, learning commitment need to be established on the part of the students in carrying out this distance learning. Several studies reporting the importance of 
students' engagement in learning have been discussed by Hakim (2016) and Rosdiana (2013). They said the existence of a commitment to learning between students and teachers had a positive effect on student achievement. The students made commitment before they participated in learning. Their commitment can be in form of emotional, normative, and sustainable commitment (Atak \& Erturgut, 2010). Building learning commitment involves many parties. It can be built between teachers, students, and parents of students (Khunsoonthornkit \& Panjakajornsak, 2018; Zainuddin \& Kamaluddin, 2012). This commitment includes time commitment, commitment to material boundaries and learning objectives, commitment in implementing communication, and commitment to maintaining comfort during the implementation of distance learning (Hanaysha, 2016).

Affective aspect can address the religious aspect of students. The commitment to learning exists between teacher and students and it is hoped that all obstacles of distance learning can be dealt with. To support learning commitment, the infrastructure needs to be considered. Strengthening the internet network is needed to develop asynchronous distance learning (Shahabadi \& Uplane, 2015; Chen et al., 2021). The results of asynchronous learning can also provide significant benefits. Shahabadi \& Uplane (2015) argue that synchronous learning requires assimilation and divergence which should be carried out by teachers to form and inculcate the character of the students.

\section{Parents' Perception}

In the view of the researcher, this means that there has been three-way communication between parents and their children, parents and teachers, and communication between teachers and students. This can happen because, before starting learning, there has been an agreement between these three elements, through the building learning commitment. This is also as stated (Khunsoonthornkit \& Panjakajornsak, 2018) that the existence of a commitment to learning will lead to changes towards goodness so that it can improve the performance of students, which in this connection is the performance in the aspect of religious attitudes.

Second, perceptions of student attitude changes when participating in distance learning from the teacher's perspective can be explained as students experience changes for the better. Students at least reduce behaviors considered negative, like helping their parents, which was very rare in the beginning, now they like to help their parents. Students who wake up late are now on time. Another teacher's point of view which states that there has been a change in student attitudes even though learning is carried out remotely and indirectly (asynchronous distance learning) is from the speed of the students in completing the assignment given by the teacher. In each lesson, the teacher assigns assignments to students. This task must be completed by the students in the agreed time. Changes in student attitudes in completing assignments are one aspect of teacher assessment. In the assessment rubric made by the teacher, the speed of completing the assignment is stated as one of the assessment points. According to the teacher, the teacher realizes that with distance learning and asynchronously, the achievement of students' cognitive competences becomes difficult to achieve. Therefore, the teacher argues that the cognitive aspect of the assessment is reduced, but added to the aspect of attitude. The teacher will give high points to students who complete assignments on time. Assessment to students will decrease according to the delay in submitting assignments to the teacher. From the perspective of research, what this teacher has done is similar to the results of her research (Chen et al., 2021).

The following researcher explores why this can happen, even if learning takes place at a distance. This study, as at the beginning of the discussion, states that the study is limited to aspects of religious affective competence, so that e-learning which is preceded by a commitment to learning between teachers and students does not reflect cognitive competence. Likewise, the development of affective competences is also not to an extreme. This religious 
affective competence that is observed is a change towards a positive religious affective even though there may be only a slight change. For example, a change from a negative attitude to a positive one, or it could be that the change is still negative, but the negativity has diminished, even though it hasn't reached a positive one.

At the same time, with regard to distance learning which is examined in this study, it is about distance learning using internet media, or more commonly referred to as e-learning. Elearning was chosen because this medium is currently one of the media considered effective for learning during the Covid-19 pandemic. Thus, to reinforce the hypothesis that distance learning can have a positive impact not only on cognitive aspects, but can also bring positive elements by developing aspects of students' religious attitudes. This is in line with the opinion of several researchers, among others, that the internet has an impact on religious co-optation and divergence. There is also an opinion (Kruger, 2005) that the internet can expand religious knowledge. In fact (Hackett, 2006) argues that the internet can be a base for spreading religion.

\section{Teacher's View/Opinion on Students' Performance}

In addition, based on the teacher's opinion of the students during distance learning, it is seen that most students experience changes in attitudes, both attitudes towards teachers, attitudes in doing assignments, and speed in completing assignments. Likewise, teachers feel helped by the commitment of the parents of students during distance learning, they still motivate their children to study and carry out worship at home. The teacher feels that the main thing in implementing distance learning is the togetherness and commitment to continue to focus on learning at home.

Based on results and discussion, there are several things that the researchers can argue, between that the discussion of this research is limited only to the achievement of the religious affective aspects of elementary school students. There are findings of positive changes in the affective aspects of students' religious during participating in asynchronous distance learning because of the learning action that uses building a collective learning commitment between teachers, students, and parents. This small research is still very likely to be developed again in a broader and deeper scope, such as extracting data for other aspects of learning, namely the cognitive and psychomotor aspects of students.

In general, this research is expected to help improve distance learning implementation. In this pandemic in particular, distance learning is urgently needed in order to avoid the spread of the corona virus through direct contact between teachers and students. Distance learning with all its advantages and disadvantages must now be implemented. Therefore, this study offers an alternative solution to a wide variety of distance learning models. As an alternative, asynchronous distance learning with an upstream learning obligation is offered. This learning obligation is agreed between teachers, students, and parents. Based on the results and analyses, it appears that this commitment to learning can contribute to a more positive affective change in the students.

This research discusses the affective aspects of Islamic religion. When it comes to learning, students' religiosity is the foundation of their character development. In line with this, instilling an attitude of religiosity in students as part of their soft skills has been a paramount mission for the teachers to achieve (Keow et al., 2015). In Indonesia, the curriculum for primary and secondary schools designs religious affective competence to achieve. Students should demonstrate their obedience to the rules of their religion and their acceptance on individual diversity as the gift from God. In this context, students should exhibit behaviours like: polite, harmonious, independent, confident and cooperative attitudes in the context of their social and daily interaction. 
All subjects taught in the school are expected to embrace the religiosity to form students' character. One of the subjects is Islamic religious education for elementary schools. One of the functions of Islamic religious education is to form a religious character in accordance with the values of national education (Ayuhana, 2015). Religious character is explicitly delivered in the subject of Islamic education. Student character can be formed on of through Islamic religious education Nasih et al. (2020). Students' character can be shaped through Islamic religious education. In line with this, basic competencies in Islamic religious education should be designed and mapped to achieve the formation of character education (Asfiati, 2017). To realize character through Islamic religious education, all the stakeholders should conduct proper management to ensure best educational practice (Amilda \& Wati, 2016). It is expected that by conducting Islamic religious education, the schools can contribute to their students' character development in an integrative manner (Hidayat et al., 2020).

The government has regulated Islamic religious education curriculum for elementary schools. In accordance with the Regulation of the Minister of Education and Culture Number 37 of 2018, the basic competencies of Islamic religious education include accepting and carrying out the teachings of their religion, getting used to praying before and after learning, and believing that respectful and obedient behaviour to parents and teachers is a reflection of faith.

The competence of students in this aspect of religious attitudes is at the centre of the research. These attitudes serve as the basis for the instrument to reach the affective aspect of religion. Regarding this aspect of religious attitudes, the United States and Europe are also developing education based on religion. In Islam, to implement the Islamic learning environment, there are four pillars to take into consideration. Learning is indicated by changes in behaviour resulting from experience. This is to say that learning means to observe, read, imitate, try, listen, learning is marked by changes in performance and this learning is a process or a procedure (Baroroh, 2004). The limitation of religious affective competence that will be examined in the research also refers to Baroroh's opinion. In addition, it is necessary to increase this affective aspect is to build better student character (Baharun \& Maryam, 2019; Nasih et al., 2020)

There are some limitations of this study. The limitations the researchers experienced were the sample and population choices, the limited depth of discussion focused on the affective aspect, the limitations of the very short research time. The duration of the research will certainly affect the reliability and consistency of the research results.

In order to make a comprehensive contribution, several things are suggested that, among other things, expand the scope of research and broaden the depth of discussion not only to affective aspects but also to cognitive and psychomotor aspects. In addition, by extending the research period in order to increase reliability and informative value.

\section{CONCLUSION}

It turns out that studies resulted distance learning ineffective for affective competency are not proven, as it found success in changing better students' attitudes though carried out asynchronously. The implementation of learning asynchronously with parents' participatory approach made possibly different results compared to the initial assumption which says that it would be very difficult to change affective competency by distance learning.

This study shows that the problem must be solved by making distance learning effective both in the attainment of cognitive, affective, and psychomotor competencies. In line with that, more comprehensive policies are needed to change people's perceptions about the possibility of distance learning. What is likely that distance learning will be maintained if the Covid-19 pandemic is not over. Meanwhile, for educators, it is necessary to develop the idea 
that distance learning can also develop the affective aspect of religion. The development of religious affective students can be developed through e-learning. The results of the findings and analysis conducted by researchers, it can be concluded that e-learning is very possible to develop religious affective competence, but must be accompanied by strengthening learning commitment.

\section{BIBLIOGRAPHY}

Abuhammad, S. (2020a). Barriers to Distance Learning during the COVID-19 Outbreak: A Qualitative Review from Parents' Perspective. Heliyon, 6(11), e05482. https://doi.org/10.1016/j.heliyon.2020.e05482

Abuhammad, S. (2020b). Heliyon Barriers to Distance Learning during the COVID-19 Outbreak: A Qualitative Review from Parents' perspective. Heliyon, 6(August), e05482. https://doi.org/10.1016/j.heliyon.2020.e05482

Adams, C. M., \& Cross, T. L. (2000). Distance Learning Opportunities for Academically Gifted Students. The Journal of Secondary Gifted Education, XI(2), 88-96.

Allen, M. (2017). Designing Online Asynchronous Information Literacy Instruction Using the ADDIE Model. Distributed Learning. Elsevier Ltd. https://doi.org/10.1016/B978-0-08-1005989.00004-0

Amilda \& Wati, N. (2016). Manajemen Kurikulum Pendidikan Agama Islam ( Pai ) di Sekolah Dasar Islam Terpadu (Sd It) Harapan Mulia Palembang. Jurnal of Islamic Education Management, 2(2), 16-30. Retrieved from http://jurnal.radenfatah.ac.id/index.php/Elidare

Arulogun, O. T., Akande, O. N., Akindele, A. T., \& Badmus, T. A. (2020). Survey Dataset on Open and Distance Learning Students' Intention to Use Social Media and Emerging Technologies for Online Facilitation. Data in Brief, 31, 105929. https://doi.org/10.1016/j.dib.2020.105929

Asfiati. (2017). Analisis Kurikulum Pendidikan Agama Islam Pra dan Pasca Undang-Undang RI Nomor 20 Tahun 2003 Tentang Sistem Pendidikan Nasional. Studi Multidisipliner: Jurnal Kajian Keislaman, 4(1), 1-21. https://doi.org/10.24952/multidisipliner.v4i1.921

Atak, M., \& Erturgut, R. (2010). An Empirical Analysis on the Relation between Learning Organization and Organizational Commitment. Procedia Social and Behavioral Sciences, 2(2), 3472-3476. https://doi.org/10.1016/j.sbspro.2010.03.537

Ayuhana, M. M. (2015). Perkembangan Kurikulum Pendidikan Agama Islam Sekolah Dasar di Indonesia. Jurnal Tarbawi, 12(2), 171. https://doi.org/10.34001/tarbawi.v12i2.512

Baharun, H., \& Maryam, S. (2019). Building Character Education Using Three Matra of Hasan Al- Banna's Perspective in Pesantren, 4(2), 51-62. https://doi.org/10.15575/jpi.v4i2.2422

Baroroh, R. U. (2004). Proses Belajar Mengajar dan Aplikasinya Dalam Pembelajaran Pendidikan Agama Islam. Uin Kalijaga.

Bloom, B. S., Engelheart, M. D., Furst, E. J., \& Et.all. (1956). Taxonomy of Educational Objecties: Classification of Educatioanal Goals. In Handbook 1 Cognitive Domain, 25-39. Michigan: David McKay Company.

Bower, M., Dalgarno, B., Kennedy, G. E., Lee, M. J. W., \& Kenney, J. (2015). Computers \& Education Design and Implementation Factors in Blended Synchronous Learning Environments : Outcomes from A Cross-Case Analysis. Computers \& Education, 86, 1-17. https://doi.org/10.1016/j.compedu.2015.03.006

Cai, Y., \& Mehari, Y. (2015). Theory and Method in Higher Education Research Vol. 1. in J. Huisman \& M. Tight, Eds. London, United Kingdom. 
Chen, Z., Liao, W., Hua, K., Lu, C., \& Yu, W. (2021). Towards Asynchronus Federated Learning for Heterogeneous Edge-Powered Internet If Things. Digital Communications and Networks. https://doi.org/10.1016/j.dcan.2021.04.001

Chertoff, J. D., Zarzour, J. G., Morgan, D. E., Lewis, P. J., Canon, C. L., \& Harvey, J. A. (2020). The Early Influence and Effects of the COVID-19 Pandemic on Resident Education and Adaptations. Journal of the American College of Radiology, 17(10), 1322-1328. https://doi.org/10.1016/ j.jacr.2020.07.022

Christopher, R., de Tantillo, L., \& Watson, J. (2020). Academic Caring Pedagogy, Presence, and Communitas in Nursing Education during the COVID-19 Pandemic. Nursing Outlook, 68(6), 822-829. https://doi.org/10.1016/j.outlook.2020.08.006

Costa, R. D., Souza, G. F., Valentim, R. A. M., \& Castro, T. B. (2020). The Theory of Learning Styles Applied to Distance Learning. Cognitive Systems Research, 64, 134-145. https://doi.org/10.1016/j.cogsys.2020.08.004

Creswell, J. W. (2014). Research Design_Qualitative, Quantitative, and Mixed Method Approaches. Los Angeles: SAGE publications.

Davis, C. R., Grooms, J., Ortega, A., Rubalcaba, J. A., \& Vargas, E. (2021). Distance Learning and Parental Mental Health During COVID-19. Educational Researcher, 50(1), 61-64. https://doi.org/10.3102/0013189X20978806

Dickey, M. D. (2003). Teaching in 3D: Pedagogical Affordances And Constraints of 3D Virtual Worlds for Synchronous Distance Learning. Distance education, 24(1), 105-121. https://doi.org/10.1080/01587910303047

Fadillah, E. N. (2017). Keterampilan Proses Sains Siswa SMA Development of Assessment Instruments To Measure The Science Process Skills Of High School Students, 1, 123134.

Fagell, P. L. (2020). Career Confidential: Distance Learning Frustrations. Phi Delta Kappan, 102(3), 66-67. https://doi.org/10.1177/0031721720970708

Gazali, E. (2018). Kendala Pemanfaatan Internet Sebagai Media Pembelajaran Jarak Jauh Fenomenologi Komunitas Homeschooling. Pascasaraja Universitas Prof. Dr. Moestopo, V(1), $10-31$.

Hackett, R. I. J. (2006). Religion and the Internet. ISSN 0392-1921, 67-76. https://doi.org/10.1177/0392192106069015

Hakim, A. R. (2016). Prestasi Belajar Matematika Ditinjau dari Sikap dan Komitmen Diri Peserta Didik pada Pelajaran Matematika. JKPM Universitas Indraprasta PGRI Jakarta, 02(01), 24-36.

Hanaysha, J. (2016). Testing the Effects of Employee Engagement, Work Environment, and Organizational Learning on Organizational Commitment. Procedia - Social and Behavioral Sciences, 229, 289-297. https://doi.org/10.1016/j.sbspro.2016.07.139

Hasanah, A., Sri, A., Rahman, A. Y., \& Danil, Y. I. (2020). Analisis Aktivitas Belajar Daring Mahasiswa pada Pandemi COVID-19. Retrieved from http://digilib.uinsgd.ac.id/id/eprint/30565

Hidayat, T., Rizal, A. S., Abdussalam, A., \& Fawwaz, A. G. (2020). Designing Islamic Values Integration into Sociology Learning. Jurnal Pendidikan Islam, 6(1), 37-56. https://doi.org/10.15575/jpi.v6i1.8119

Holotescu, C., Grosseck, G., \& Danciu, E. (2014). Educational Digital Stories in 140 Characters: Towards a Typology of Micro-Blog Storytelling in Academic Courses. Procedia - Social and Behavioral Sciences, 116, 4301-4305. https://doi.org/10.1016/j.sbspro.2014.01.936

Iswandi, E. A. (1999). Improving Distance Learning of Midwives in Indonesia. Journal of Health Management, 1(2), 323-345. https://doi.org/10.1177/097206349900100209 
Keow, T., Huwaina, S., \& Kanokorn, S. (2015). Soft Skills Of Leaders And School Improvement In High Performing Schools. Procedia - Social and Behavioral Sciences, 191(2011), 2127-2131. https://doi.org/10.1016/j.sbspro.2015.04.652

Khunsoonthornkit, A., \& Panjakajornsak, V. (2018). Kasetsart Journal of Social Sciences Structural Equation Model to Assess The Impact of Learning Organization and Commitment on The Performance of Research Organizations. Kasetsart Journal of Social Sciences, 39(3), 457-462. https://doi.org/10.1016/j.kjss.2018.07.003

Kruger, O. (2005). Discovering the invisible internet. Heidelberg Journal of Religions on the Internet, $1,75-76$.

Lapitan, L. Ds. Jr., Tiangco, C. E., Angela, D., Sumalinog, G., Sabarillo, N. S., \& Mark, J. (2021). An Effective Blended Online Teaching and Learning Strategy During the COVID-19 Pandemic. Education for Chemical Engineers, 35(May 2020), 116-131. https://doi.org/10.1016/j.ece.2021.01.012

Mehri, M., \& Uplane, M. (2015). Synchronous and Asynchronous E-Learning Styles and Academic Performance of E-Learners, 176, 129-138. https://doi.org /10.1016/j.sbspro.2015.01.453

Mercurio, Z. A. (2015). Affective Commitment as a Core Essence of Organizational Commitment: An Integrative Literature Review. Human Resource Development Review, 14(4), 389-414. https://doi.org/10.1177/1534484315603612

Mignon, A., \& Jurie, F. (2012, June). Pcca: A new approach for distance learning from sparse pairwise constraints. In 2012 IEEE conference on computer vision and pattern recognition (pp. 2666-2672). IEEE. https://doi.org/10.1109/CVPR.2012.6247987

Moore, J. L., Dickson-deane, C., \& Galyen, K. (2011). Internet and Higher Education ELearning, Online Learning, And Distance Learning Environments: Are They The Same? The Internet and Higher Education, 14(2), 129-135. https://doi.org/10.1016/j.iheduc.2010.10.001

Nasih, A. M., Sultoni, A., Thoriquttyas, T., Yani, A., Ramli, S., \& Umar, M. (2020). Applying Participatory Observation in Islamic Education to Improve Students' Character. JPI UIN SGD, 6(2), 145-152. https://doi.org/10.15575/jpi.v6i2.9756

Ningsih, S. (2020). Persepsi Mahasiswa Terhadap Pembelajaran Daring Pada Masa Pandemi Covid-19. JINOTEP (Jurnal Inovasi dan Teknologi Pembelajaran): Kajian Dan Riset dalam Teknologi Pembelajaran, 7(2), 124-132. https://doi.org/ 10.17977/um031v7i22020p124

O’Leary, D. E. (2019). Technology Life Cycle and Data Quality: Action and Triangulation. Decision Support Systems, 126(May), 113139. https://doi.org/10.1016/j.dss.2019.113139

Porter, R. L., \& Latham, G. P. (2013). The Effect of Employee Learning Goals and Goal Commitment on Departmental Performance. Journal of Leadership and Organizational Studies, 20(1), 62-68. https://doi.org/10.1177/1548051812467208

Jena, P. K. (2020). Impact of Pandemic COVID-19 on Education in India. International Journal of Current Research, 12. Retrieved from http://journalcra.com/article/impactpandemic-covid-19-education-india

Qazi, A., Qazi, J., Naseer, K., Zeeshan, M., Qazi, S., Abayomi-alli, O., \& Haruna, K. (2021). Children and Youth Services Review Adaption Of Distance Learning To Continue The Academic Year Amid COVID-19 Lockdown. Children and Youth Services Review, 126(April), 106038. https://doi.org/10.1016/j.childyouth.2021.106038

Rahmawati, S. D. (2009). Kendala Pelaksanaan Pembelajaran Jarak Jauh Melalui Internet Pada Mahasiswa PJJ S1 Pgsd Universitas Negeri Semarang. Unnes Semarang. 
Rosdiana, D. (2013). Pengaruh Kompetensi Guru dan Komitmen Mengajar Terhadap Efektivitas Proses Pembelajaran Serta Implikasinya Pada Hasil Belajar Siswa Dalam Mata Pelajaran Ekonomi. Jurnal Penelitian Pendidikan, 13(2). https://doi.org/ 10.17509/jpp.v13i2.3433

Saidi, R. M., Sharip, A. A., Abd Rahim, N. Z., Zulkifli, Z. A., \& Md Zain, S. M. (2021). Evaluating Students' Preferences of Open and Distance Learning (ODL) Tools. Procedia Computer Science, 179, 955-961. https://doi.org/10.1016/j.procs.2021.01.085

Schaible, B., Annie, F., Seybold, D., \& Calhoun, B. C. (2020). Ecological study of Effects of Industrial Watershed on Müllerian Anomalies In An Obstetric Population. Ecotoxicology and Environmental Safety, 110819. https://doi.org/10.1016/j.ecoenv.2020.110819

Shahabadi, M. M., \& Uplane, M. (2015). Synchronous and Asynchronous E-Learning Styles and Academic Performance of E-Learners. Procedia - Social and Behavioral Sciences, 176, 129-138. https://doi.org/10.1016/j.sbspro.2015.01.453

Soegijapranata, U. (2016). Panduan Wawancara. Semarang. Retrieved from https://core.ac.uk/download/pdf/80825731.pdf

Sugiyono. (2014). Metode Penelitian Pendidikan, Pendekatan Kuantitatif. Bandung: Alfabeta. Retrieved from https://www.pdfdrive.com/prof-dr-sugiyono-metode-penelitianpendidikan-pendekatan-kuantitatif-intro-d56379751.html

Szeto, E. (2014). A Comparison of Online / Face-To-Face Students ' and Instructor' S Experiences: Examining Blended Synchronous Learning Effects. Procedia - Social and Behavioral Sciences, 116, 4250-4254. https://doi.org/10.1016/j.sbspro.2014.01.926

Tayo, O., Noah, O., Tosin, A., \& Alabi, T. (2020). Survey Dataset on Open and Distance Learning Students' Intention to Use Social Media and Emerging Technologies for Online Facilitation. Data in Brief, 31, 105929. https://doi.org/10.1016/j.dib.2020.105929

Tsipianitis, D., \& Groumpos, P. (2018). University Asynchronus Distance Learning Programs to Enhance Interregional Sustainable Development. IFAC-PapersOnLine, 51(30), 346351. https://doi.org/10.1016/j.ifacol.2018.11.329

Vu, C., Hoang, A., \& Than, V. (2020). Dataset of Vietnamese Teachers' Perspectives and Perceived Support During the COVID-19 Pandemic, 31. https://doi.org/ 10.1016/j.dib.2020.105788

Zainuddin, A., \& Kamaluddin, N. (2012). Exploring Malay Student's Commitment in Online Learning - A Case of Business Management Students. Procedia - Social and Behavioral Sciences, 67, 81-92. https://doi.org/10.1016/j.sbspro.2012.11.309 